\title{
Influence of Compensation on Work Performance in the District Office of Bissappu, Bantaeng Regency
}

\author{
Widya Permata IS ${ }^{1}$, Jamaluddin', Muh. Sirajuddin Saleh ${ }^{3}$, Sitti Hardiyanti Arhas ${ }^{4}$ \\ 1,2,3,4 Universitas Negeri Makassar \\ E-mail: widyapis@gmail.com
}

\begin{abstract}
The potential of every human resource in each office must be utilized as well as possible so as to provide optimal output. This study aims to determine the effect of compensation on employee performance in the Bissappu District Office, Bantaeng Regency. This study uses a quantitative approach with a population of 52 and determining the amount of 5 percent of the population so that 46 samples are obtained. Of the 46 samples 44 of them were made as Respondents and 2 were used as Informants. Data collection techniques observation, questionnaire, interview, and documentation, while the data analysis technique used is the percentage statistics. The results showed that the effect of compensation in the District Office of Bissappu in Bantaeng Regency was classified as very high in terms of indicators of direct compensation and indirect compensation. The work performance of employees in the Bissappu District Office of Bantaeng Regency is classified in the very high category in terms of indicators of work quality, work quantity, level of reliability, and attitude. Hypothesis testing results indicate that there is a significant relationship between compensation for employee performance in the District Office of Bissappu, Bantaeng Regency.
\end{abstract}

Keywords: Compensation, employees, work performance

\section{INTRODUCTION}

Human resources are the main actors that drive the governance of an organization both private and government organizations. So that human resources are used as the main actors in the organization, of course, must be filled by people who are elected. In other words, those who can sit and carry out the task are people who have more capabilities than others who have an important role either individually or in groups. Every organization will always try to improve the ability of its organization, one of the ways taken is to improve the ability of its employees, for example by providing appropriate compensation by calculating work performance, with the hope that what the organization's goals will be achieved. Improving the quality of employee resources becomes very urgent and needs to be done in a planned, directed and continuous manner in order to improve the ability and professionalism (Akhmad, 2016; Amirullah \& Saleh, 2015; Norani, Amirullah, \& Darwis, 2015).

Copyright () 2019 Universitas Negeri Makassar. This is an open access article under the CC BY license (http://creativecommons.org/licenses/by/4.0/) 


\footnotetext{
106 Jurnal Administrare: Jurnal Pemikiran Ilmiah dan Pendidikan Administrasi Perkantoran

Volume 6 Number 2 July- December 2019. Pages 105-114
}

The office must pay attention to the principle of justice in determining its compensation policy (Handoko, 2011; Wairooy, 2017). Internal justice or consistency means that the amount of compensation must be related to the relative value of the works. Such as providing salaries to employees on a periodic basis, providing benefits to employees who have participated well in achieving organizational goals. And the most important point is giving incentives to employees because of the success of their work performance. The existence of human resources in an office plays a very important role. The workforce has great potential to carry out office activities. The potential of every human resource in each office must be utilized as well as possible so as to provide optimal output (Gani, 2014; Saleh, 2014).

The Bissappu sub-district office has 52 sub-districts, of which 26 civil servants and 26 are still honorary so that the compensation greatly influences the work performance of the subdistrict apparatus, especially the honorary status. The Bissappu Department of Health is one of the offices that has the most subdistricts in Bantaeng Regency. The form of compensation received by the sub-district apparatus is in the form of direct and indirect compensation with different nominal amounts. Differences in compensation are made because of differences in positions held by employees. The compensation is given by the office certainly has a significant impact on employee work performance. Wherewith the compensation given, the employees feel more valued than what they have done and the compensation will also be able to increase the enthusiasm of the employees to always perform better.

\section{METHOD}

The purpose of this study was to determine whether there is an effect of compensation on employee performance in the District Office of Bissappu, Bantaeng Regency. This study has two variables, namely the independent variable and the dependent variable. The independent variable $(\mathrm{X})$ is compensation and the dependent variable $(\mathrm{Y})$ is work performance. Therefore, this research approach is a quantitative approach. Indicators for the variable $\mathrm{X}$ are direct compensation and indirect compensation. While indicators for the $\mathrm{Y}$ variable are quality of work, quantity of work, level of reliability and attitude. The measurement variable used is a Likert scale. The total population of 52 employees, while those selected as the research sample were 46 employees. Data collection techniques used were observation, questionnaire, interview, and documentation. Data analysis techniques consisted of descriptive statistical analysis and inferential statistical analysis. Descriptive statistical analysis consists of percentage, mean and standard deviation. Whereas inferential statistical analysis consists of product-moment correlation analysis and regression analysis that was previously tested by data normality.

\section{RESULT AND DISCUSSION}

In order to determine the effect of compensation on employee work performance in the Bissappu District office in Bantaeng Regency, a questionnaire instrument was used as a data collection technique for variables $\mathrm{X}$ and $\mathrm{Y}$. Furthermore, in hypothesis testing, quantitative tests were performed using statistical formulas and computer software with the Statistical Product program Standard Solution (SPSS) 20 which is considered relevant for data analysis which aims 
to determine the level of influence of Compensation on employee work performance in the Bissappu District Office of Bantaeng

\section{Compensation Description}

Descriptive analysis is intended to determine the level of employee compensation in the Bissappu District Office of Bantaeng Regency. The data presented in this study are data obtained as a result of scores from the research questionnaire related to the compensation variable. In the compensation, variable consists of two indicators, namely direct compensation and indirect compensation. For more details can be seen in Table 1.

Table 1. Compensation Data Analysis Results

\begin{tabular}{lrrcc}
\hline Indicator & n & \multicolumn{1}{c}{ N } & Persentase (\%) & Category \\
\hline Direct compensation & 931 & 1100 & 84,64 & Very high \\
Indirect compensation & 762 & 880 & 86,59 & Very high \\
\hline Total & $\mathbf{1 6 9 3}$ & $\mathbf{1 9 8 0}$ & & Very high \\
\hline
\end{tabular}

Source: Data processing results

Direct compensation which is an indicator of compensation is in the very high category with a percentage level of 84.64 percent. The percentage results show that employees in the Bissappu District office in Bantaeng Regency have received direct compensation in the form of salary/wages. This is consistent with the results of an interview with Mr. M. Amin Basi, S. Sos, M. Si (Camat Bissappu) revealed that "regarding giving direct compensation to employees raises no suspicion that wages or bonuses have been deducted or compensated which is given either were or not until the intended hand ".

Indirect compensation which is an indicator of compensation is in the very high category with a percentage level of 86.59 percent. The percentage results show that employees in the Bissappu District office in Bantaeng Regency have received indirect compensation in the form of benefits, health insurance, and promotion of positions. This is in accordance with the results of an interview with Mr. Andi Yakub, S.STP (Sekcam Bissappu) who explained that "Indirect compensation or benefits in employees are different from benefits in the company. If employee benefits have a name for office benefits (Structural Position), so indirect compensation is different for each employee."

Based on the results of the percentage of compensation variables in the District Office of Bissappu, Bantaeng Regency is in the very high category with a percentage level of 85.51 percent, this is in accordance with the opinion (Sugiyono, 2017) that $81 \%-100 \%$ categorized very high. This shows that the provision of compensation in the Bissappu District office in Bantaeng Regency is in the very high category in terms of indicators of direct compensation and indirect compensation. While the mean of the compensation variable is 38.47 with a standard deviation of 2.334 .

Based on the analysis and interview results it can be concluded that the compensation picture is in the very high category, which is more likely to be influenced by indirect 


\section{Jurnal Administrare: Jurnal Pemikiran Ilmiah dan Pendidikan Administrasi Perkantoran \\ Volume 6 Number 2 July- December 2019. Pages 105-114}

compensation indicators that have a higher percentage than the other indicators which is at the percentage level of 86.59 percent.

\section{Description of Work Performance}

Descriptive analysis is intended to determine the level of work performance of employees in the District Office of Bissappu, Bantaeng Regency. The data presented in this study are data obtained as a result of scores from research questionnaires related to work performance variables. The employee performance variable consists of four indicators, namely quality of work, the quantity of work, level of reliability and attitude. For more details, can be seen in Table 2

Tabel 2. Work Performance Data Analysis Result

\begin{tabular}{lcccl}
\hline Indicator & n & N & Persentase (\%) & Category \\
\hline Work quality & 586 & 660 & 88,79 & Very high \\
Work quantity & 393 & 440 & 89,32 & Very high \\
Reliability level & 386 & 440 & 87,73 & Very high \\
Attitude & 781 & 880 & 88,75 & Very high \\
\hline Total & $\mathbf{2 1 4 6}$ & $\mathbf{2 4 2 0}$ & & Very high \\
\hline
\end{tabular}

Source: Data processing results

The quality of work that is an indicator of work performance is in the very high category with a level of 88.79 percent. The percentage results show that employees in the District Office of Bissappu, Bantaeng Regency can complete office work in accordance with the expected work. This is in line with the results of an interview with Mr. M. Amin Basi, S. Sos, M.Sc (Bissappu Sub-District Head) who revealed that, "work performance produced by employees in terms of quality depends on the individual employees because there is a level of self-awareness itself, but as can be seen now the work performance of employees has been going well especially with the ASN law on employees as state servants being demanded that the work performance produced is accountable and has competence in their respective fields ".

The quantity of work that is an indicator of work performance is in the very high category with a percentage level of 89.32 percent. The percentage results indicate that employees in the District Office of Bissappu, Bantaeng Regency can work in accordance with the specified target (quantity) of work. This is consistent with the results of an interview with Mr. Andi Yakub, SSTP (Sekcam Bissappu) who stated that "Almost all employees work according to targets and use work time as efficiently as possible so that their work performance is satisfactory".

The level of reliability that is an indicator of work performance is in the very high category with a percentage level of 87.73 percent. The percentage results indicate that employees work according to instructions from the leadership. This is consistent with the results of an interview with Mr. M. Amin Basi, S. Sos, M.Si (Bissappu Sub-District Head) who stated that, "the level of employee reliability varies, which is above standard and still standard depending on capacity. One of the things that affects the educational background and perseverance. It is very visible that the reliability of employees with a bachelor's education background compared to those who 
only graduate from high school. But there are also some employees with low education, such as high school, but the level of reliability is above the standard because of the intention to study diligently and follow the rules ".

Attitudes that are indicators of work performance are in the very high category with a percentage level of 88.75 percent. The percentage results indicate that the attitude between the leaders and subordinates is well established. This is consistent with the results of an interview with Mr. Andi Yakub, SSTP (Sekcam Bissappu) who stated that "the priority attitude is that the staff respects the leader, the leader also respects his subordinate staff".

Based on the results of the percentage of work performance variables in the District Office of Bissappu, Bantaeng Regency is in the very high category with a percentage level of 88.68 percent, this is in accordance with the opinion (Sugiyono, 2017) that $81 \%-100 \%$ categorized very high. This shows that the level of work performance in the District Office of Bissappu Bantaeng Regency is in the very high category in terms of indicators of work quality, work quantity, level of reliability, and attitude. While the mean of the work performance variable is 48.77 with a standard deviation of 2.568 .

Based on the results of analysis and interviews it can be concluded that the level of work performance in this office is in the very high category, which is more likely to be influenced by indicators of work quantity that has a higher percentage than other indicators which is at the percentage level of 89.32 percent.

\section{The Influence of Compensation on Work Performance}

\section{a. Data Normality Test}

Before conducting further analysis, it is first necessary to know whether the data of this study have met the requirements for using statistics that will be used in hypothesis testing. Testing the analysis requirements for statistical use is data obtained at least normally distributed. Data normality test is intended to determine the normality of data from the compensation variable and work performance.

The criterion used is to compare the price of chi square and chi square tables. The condition for chi squared is that chi square is smaller or equal to the chi square table $\left(\mathrm{X}_{\mathrm{h}}^{2} \leq \mathrm{X}_{t}^{2}\right)$ then henceforth the data is declared normally distributed, if something happens otherwise the data is said to be abnormal. The results of normalcy data in this study after being processed using SPSS 20 can be seen in Table 3.

Table 3. Data Normality Test

\begin{tabular}{lcccc}
\hline \multicolumn{1}{c}{ Variable } & $\mathbf{X}_{\mathbf{h}}{ }^{2}$ & $\mathbf{X}_{\mathbf{t}}{ }^{2}$ & Df & Meaning \\
\hline X Compensation & 20,500 & 21,026 & 12 & Normal \\
Y Work Performance & 23,500 & 23,685 & 14 & Normal
\end{tabular}

Source: Data processing resultsSPSS 20 
\begin{tabular}{l|l}
110 & Jurnal Administrare: Jurnal Pemikiran Ilmiah dan Pendidikan Administrasi Perkantoran \\
Volume 6 Number 2 July- December 2019. Pages 105-114
\end{tabular}

From table 3 it can be seen that the calculated chi-squared $\left(\mathrm{X}_{\mathrm{h}}^{2}\right)$ compensation variable is 20,500 smaller than the chi-squared table $\left(\mathrm{X}_{\mathrm{t}}^{2}\right)$, which is 21,026 with a value of Df 12 . While the work performance variable in the Bissappu District office the chi-square value is 23,500 smaller than chi the square of the table is 23,685 with a value of Df 14 . From the normality test, the data shows that the compensation variable and work performance variable in the Bissappu District office in Bantaeng Regency, are declared normally distributed because they meet the requirements.

\section{b. Product-moment Correlation Analysis}

The product-moment correlation test is intended to determine whether there is a relationship between compensation for employee performance in the Bissappu District office in Bantaeng Regency. The following shows the correlation test results in Table 4:

Tabel 4. Summary of Product Moment Correlation Analysis Results

\section{Model R R Square Adjusted R Square Std. Error of the Estimate}

\begin{tabular}{lllll}
\hline 1 & $.354^{\mathrm{a}}$ & .125 & .104 & 2.43089
\end{tabular}

Source: Data processing results SPSS 20

Based on the correlation analysis of the product-moment calculation results obtained by the correlation between the implementation of the filing system $(\mathrm{X})$ and employee performance (Y) that is $r$ of 0.354 after being interpreted according to opinion (Sugiyono, 2017), The score is in the interval 0.20-0.399 which has a low relationship level.

\section{c. Simple Linear Regression Analysis}

The purpose of using a simple linear regression is to test the hypothesis in this study that "allegedly there is a significant influence between compensation for employee performance in the District Office of Bissappu, Bantaeng Regency". Testing criteria is if $\mathrm{F}_{\text {count }}$ greater than $\mathrm{F}_{\text {table }}$ at a significant level of $5 \%$ then $\mathrm{H}_{0}$ rejected stating that there is no effect of compensation on employee performance and $\mathrm{H}_{0}$ accepted which states that there is an effect of compensation on employee work performance. For more details, see Table 5:

Table 5. Analyst Summary of Simple Linear Regression

\begin{tabular}{lccccc}
\hline \multicolumn{1}{l}{ Variable } & $\mathbf{B}$ & $\mathbf{F}_{\text {count }}$ & Sig & $\mathbf{F}_{\text {table }}$ & Sig \\
\hline Constant & 33,872 & & & 5,565 & 0.000 \\
& & 6,014 & 0.018 & & \\
Compensation & 0,387 & & & 2,452 & 0.018 \\
\hline
\end{tabular}

Source: Data processing results SPSS 20 
To find out the simple linear regression $\mathrm{F}$ test is used through the ANOVA table. The accepted hypothesis is $\mathrm{H}_{0}: \alpha: \beta=0$ resist $\mathrm{H}_{1}: \alpha: \neq 0$ or $\beta \neq 0$. From the results of the calculation of the $F$ test obtained $F_{\text {count }}$ is 6,014 with $F_{\text {table }}(0.05: 1: 44)$ of 4.06 which means $\mathrm{F}_{\text {count }}$ bigger than $\mathrm{F}_{\text {table }}$, because $\mathrm{F}_{\text {count }}$ bigger than $\mathrm{F}_{\text {table }}$ so $\mathrm{H}_{0}$ is resist and $\mathrm{H}_{1}$ accepted which means there is a dependence of the compensation variable on work performance so that the results of data processing directly in this study with the hypothesis that "allegedly there is an influence of compensation on employee performance in the District Office of Bissappu Banateng Regency" can be Accepted .

\section{Discussion}

\section{Compensation Description}

The process of administering wages or salaries (called compensation) involves a consideration or balance calculations. Compensation is something that is considered as something comparable. In staffing, monetary gifts are compensation given to employees in appreciation of their services. Forms of remuneration, forms of wages, and salaries are used to regulate financial giving between superiors and subordinates.

Compensation plays an important role in an office, in order to obtain an objective in accordance with the previous plan, according to the results of the study showed that in the Bissappu District Office Bantaeng Regency the application of compensation is in the very good category, seen from several indicators namely direct compensation and indirect compensation. In accordance with the results of the study showed that direct and indirect compensation is in the very good category. This shows that the provision of direct and indirect compensation to the staff of the Bissappu District office has been going well. Where the provision of direct compensation such as salaries or wages of each employee is clear according to the salary rates of other local governments as well as regarding other incentives/bonuses according to employee work performance. And the benefits of employees are different from the benefits of the company. If employee benefits have a name for office benefits (Structural Position), the amount of indirect compensation is not evenly distributed for each employee. Therefore, giving compensation is very important for every employee in supporting work performance both directly and indirectly.

\section{Description of Work Performance}

The term performance comes from the word Job Performance or actual Performance (work performance or actual achievement achieved by someone. Understanding work performance is the work in quality, quantity, level of reliability, attitudes achieved by an employee in carrying out their duties in accordance with the responsibilities given to her.

The results showed that the work performance of employees in the District Office of Bissappu, Bantaeng Regency was in the very good category. This is indicated by work performance indicators namely work quality, work quantity, level of reliability, and employee attitude. Quality of work is accuracy in work that employees must pay attention to so there are no mistakes in the number of jobs. In addition, employees must also be efficient in using work time so that work can be completed on target. In addition, factors that must be considered in 
\begin{tabular}{l|l}
112 Jurnal Administrare: Jurnal Pemikiran Ilmiah dan Pendidikan Administrasi Perkantoran \\
Volume 6 Number 2 July- December 2019. Pages 105-114
\end{tabular}

supporting employee work performance are the level of reliability and attitude. In working, employees must be reliable in completing tasks given by the leadership and work according to the applicable rules so that the work is completed quickly and precisely by prioritizing a good attitude of cooperation between the leader and colleagues. Therefore employee work performance is very important in supporting the success of an office because it has formed a great potential that will move to achieve the office's objectives so that it can be seen how employees can be responsible and provide maximum service to the community.

\section{The Influence of Compensation on Work Performance}

From the results of the study found that there is a significant relationship between compensation for employee performance in the District Office of Bissappu, Bantaeng Regency with a low level of relationship. In accordance with the results of hypothesis testing it was found that there was an influence between the compensation variables on work performance in the Bissappu District Office. Thus, the hypothesis says that "there is an effect of compensation on work performance in the Bissappu District Office", otherwise accepted.

Job performance is basically a key factor for developing an office effectively and efficiently, because there is a better program of human resources in the office, especially for employees who have the knowledge (skills), and abilities (ability) so as to produce an achievement for each particular employee. As a form of retribution for employee work performance, namely by providing direct and indirect compensation so that employees feel satisfaction with what they have done.

Mc. Gregor stated that "Work performance is very closely related to training and development issues, career planning/promotion and wage issues". With the existence of direct compensation and indirect compensation, statements can be fulfilled by Mc. Gregor.

\section{CONCLUSION}

Based on the results of the study, archival management at the East Pasimasunggu District office in the Selayar Archipelago Regency is in a fairly good category. This is demonstrated through the focus of research, namely: the creation of the archive is in the good enough category, the use of the archive is in the good enough category, the storage of the archive is in the good enough category, the maintenance of the archive is in the not good category, depreciation and annihilation are in the not good category.

\section{REFERENCES}

Akhmad, A. (2016). Pengaruh Profesionalisme Sumber Daya Manusia terhadap Kinerja Pelayanan di Kantor Samsat Pinrang. Jurnal Office, 2(2), 103-108.

Amirullah, A. H., \& Saleh, S. (2015). Pengaruh Budaya Organisasi terhadap Kinerja Pegawai Pada Kantor Lembaga Penjaminan Mutu Pendidikan (LPMP) Provinsi Sulawesi Selatan di Kota Makassar. Jurnal Office, 1(1), 24-31. 
Gani, F. S. (2014). Respon Masyarakat Terhadap Kinerja Pelayanan Publik Di Kantor Kecamatan Pinogaluman. Jurnal Ad'ministrare: Jurnal Pemikiran Ilmiah dan Pendidikan Administrasi Perkantoran, 1(1), 62-71.

Handoko, T. H. (2011). Manajemen Personalia dan Sumber Daya Manusia. Pengantar Manajemen.

Norani, M., Amirullah, A. H., \& Darwis, M. (2015). Efektivitas Kinerja Pegawai pada Kantor Kementerian Agama Kota Makassar. Jurnal Office, 1(1), 1-7.

Saleh, S. (2014). Penegakan Disiplin (Suatu Upaya Peningkatan Kinerja Pegawai). Jurnal Ad'ministrare, 1(1), 8-19.

Sugiyono. (2017). Pendekatan Kuantitatif, Kualitatif, Kombinasi, R\&D dan Penelitian Evaluasi. In Metodelogi Penelitian.

Wairooy, A. (2017). Pengaruh Disiplin Kerja dan Kompensasi Terhadap Kinerja Karyawan pada PT. Pertamina (Persero), Tbk. Pemasaran Region VII Makassar. Jurnal Ad'ministrare: Jurnal Pemikiran Ilmiah dan Pendidikan Administrasi Perkantoran, 4(1), 15-24. 
114 Jurnal Administrare: Jurnal Pemikiran Ilmiah dan Pendidikan Administrasi Perkantoran Volume 6 Number 2 July- December 2019. Pages 105-114 